\title{
Gaya Kepemimpinan terhadap Motivasi Kerja Pegawai Dinas Pariwisata dan Kebudayaan
}

\author{
AL Indah Afifah', Lise Asnur ${ }^{2}$ \\ 1,2 Universitas Negeri Padang, Padang, Indonesia
}

Keywords:

Leadership Style;

Work Motivation

\section{Kata kunci: \\ Gaya \\ Kepemimpinan; \\ Motivasi Kerja}

\section{ABSTRACT}

Abstract: There are employee complaints about communication difficulties that are too convoluted so that employees have communication difficulties in understanding the messages conveyed by the leadership. This study aims to analyze leadership style on work motivation. This study uses quantitative data types with descriptive methods. The population used in this study were all employees of the Department of Tourism and Culture. The sample technique used is probability sampling with the number of samples used is $\mathbf{5 7}$ people. Methods of data collection using a questionnaire. Data analysis used is normality test, homogeneity test and linearity test. In testing the hypothesis using a simple linear regression test. The results of data processing using SPSS version 20.00 . The results showed that the Leadership Style variable (X) showed a percentage of $89.4 \%$ in the range of 51.9 with a very good category. Work Motivation Variable $(\mathrm{Y})$ is $96.5 \%$ in the range of 67.95 with a very good category. The results of a simple linear regression obtained a calculated $F$ value of 20,834 with a sign of $0.000<0.05$ then the Leadership Style variable $(X)$ has a significant effect on the Work Motivation variable $(Y)$. Then the coefficient of determination obtained $R$ Square of 0.275 , meaning that the effect of variable $X$ on variable $Y$ is $27 \%$, while $73 \%$ is influenced by other factors. So, leadership style has a positive effect on employee motivation. The existence of this research is expected to be an illustration or input for agencies to improve their leadership style well.

Abstrak: Adanya keluhan pegawai tentang kesulitan berkomunikasi yang terlalu berbelitbelit, sehingga pegawai mengalami kesulitan komunikasi dalam memahami pesan yang disampaikan oleh pimpinan. Penelitian ini bertujuan untuk menganalisis gaya kepemimpinan terhadap motivasi kerja. Penelitian ini menggunakan jenis data kuantitatif dengan metode deskriptif. Pupulasi yang digunakan dalam penelitian ini yaitu seluruh pegawai Dinas Pariwisata dan Kebudayaan. Teknik sampel yang digunakan yaitu probability sampling dengan jumlah sampel yang digunakan adalah 57 orang. Metode pengumpulan data mengunakan kuesioner. Analisis data yang digunakan adalah uji normalitas, uji homogenitas, dan uji linearitas. Pada pengujian hipotesis menggunakan uji regresi linear sedeharna. Hasil pengolahan data dengan menggunakan SPSS versi 20.00. Hasil penelitian diperoleh variabel gaya kepemimpian $(X)$ menunjukan persentase $89,4 \%$ pada rentang $\geqslant$ 51,9 dengan kategori sangat baik. Variabel motivasi kerja (Y) sebesar $96,5 \%$ pada rentang $\geqslant 67,95$ dengan kategori sangat baik. Hasil regresi linear sederhana diperoleh nilai $\mathrm{F}$ hitung 20.834 dengan sign $0,000<0,05$ maka variabel gaya kepemimpinan $(X)$ berpengaruh secara signifikan terhadap variabel motivasi kerja ( $\mathrm{Y}$ ). Koefisien determinasi diperoleh $\mathrm{R}$ Square sebesar 0.275 . Artinya, pengaruh variabel $X$ terhadap variabel $Y$ adalah sebesar $27 \%$, sedangkan $73 \%$ dipengaruhi oleh faktor lain. Jadi, gaya kepemimpinana berpengaruh positif terhadap motivasi kerja pegawai. Adanya penelitian ini diharapkan dapat menjadi gambaran atau masukan bagi instansi untuk meningkatkan gaya kepemimpinan dengan baik.

Alamat Korespondensi:

E-mail: Alindahafifah489@gmail.com (Dharmawan)

$\begin{array}{ll}\text { History: } & \\ \text { Received } & : 25 \text { Mei } 2021 \\ \text { Revised } & : 28 \text { Mei } 2021 \\ \text { Accepted } & : \text { 10 Juni } 2021 \\ \text { Published } & : 25 \text { Juli } 2021\end{array}$

History:

Revised : 28 Mei 2021

Published : 25 Juli 2021
Publisher: Undiksha Press

Licensed: This work is licensed under a Creative Commons Attribution 3.0 License

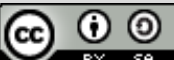




\section{Pendahuluan}

Instansi pemerintah dapat dikelola dengan baik jika memiliki sumber daya manusia atau pegawai yang mampu mengola, menggerakan, dan mencapai tujuan organisasi. Sumber daya manusia memegang peran yang sangat pentin. Sumber daya manusia dipandang sebagai faktor pendorong yang utama dalam menentukan keberhasilan suatu perusahaan (Dewi, 2021; Nabawi, 2019). Sumber daya manusia yang baik diharapkan mampu menghasilkan kinerja yang baik sesuai dengan yang diharapkan dan diinginkan instansi (Farhah et al., 2020; Meilany \& Ibrahim, 2015; Rafiditya \& Syarifuddin, 2020). Keberhasilan suatu perusahaan sangat dipengaruhi oleh tenaga kerja yang berkualitas dan mempunyai efektivitas kerja yang memadai. Potensi sumber daya manusia mempunyai peranan yang sangat penting sebagai pelaku yang terlibat langsung dalam proses pembangunan industrial saat ini (Cahyadi, 2019; Rialmi, 2020).

Namun kenyataannya, terdapat permasalahan pada komunikasi dengan pimpinan di Dinas Pariwisata dan Kebudayaan Kota Padang. Adanya keluhan pegawai tentang kesulitan berkomunikasi yang terlalu berbelit-belit, sehingga pegawai mengalami kesulitan komunikasi dalam memahami pesan yang disampaikan oleh pimpinan. Di samping itu, pimpinan menunjukkan sifat egois pada bawahan. Dalam melaksanakan pekerjaan, pimpinan tidak dapat diberi saran atau masukan, sehingga menimbulkan perasaan tertekan oleh pegawai. Kedisiplinan pegawai di Dinas Pariwisata dan Kebudayaan Kota Padang masih kurang. Hal ini dapat dilihat dari masih banyaknya pegawai yang datang ke kantor tidak tepat waktu. Terdapat juga sikap kurang peduli pimpinan terhadap permasalahan yang dihadapi, yaitu dengan tidak memberikan jalan keluar dan menyerahkan sepenuhnya kepada pegawai.

Kepimpinan dalam suatu organisasi harus mempunyai jiwa kreatif, harus bisa mepengaruhi bawahan, harus bisa mengatur, mengelola, dan memimpin bawahan dengan kemampuan yang dimilikinya. Hal ini terkait dengan gaya kepemimpinan seorang pemimpin (Sanders et al., 2017; Suherman, 2018; Wardany, 2020). Dalam memimpin suatu organisasi perlu mengembangkan anggotanya dan membangun iklim motivasi yang menghasilkan tingkat produktivitas yang tinggi. Untuk memengaruhi, mengarahkan, dan menggerakkan potensi sumber daya manusia yang diinginkan, seorang pemimpin dalam organisasi harus mampu dan perlu memberikan motivasi kepada pegawainya agar dapat bekerja secara optimal. Motivasi sangat diperlukan oleh pegawai karena dengan adanya motivasi yang baik pegawai dapat melaksanakan pekerjaannya sesuai dengan tanggung jawabnya (Amyana et al., 2014; Farhah et al., 2020). Motivasi kerja secara tidak langsung dapat berpengaruh dalam keberhasilan suatu organisasi.

Temuan penelitian sebelumnya menyatakan bahwa salah satu aspek dalam mencapai keberhasilan suatu organisasi yaitu berasal dari pegawai (Tolu et al., 2021). Temuan lain juga menyatakan bahwa kepemimpinan memiliki dampak terhadap motivasi kerja pegawai (Hanafi \& Zulkifli, 2018; Nabawi, 2019). Hal ini berarti bahwa gaya kepemimpinan yang baik akan memotivasi kerja pegawai. Seseorang yang memiliki motivasi kerja yang baik dapat diartikan bahwa seseorang tersebut telah mematuhi dan menaati peraturan yang terdapat pada organisasi. Tujuan penelitian ini yaitu menganalisis pengaruh gaya kepemimpinan pada salah satu instansi pemerintah di Kota Padang yaitu Dinas Pariwisata dan Kebudayaan Kota Padang. Adanya penelitian diharapkan dapat membantu meningkatkan motivasi kerja pegawai.

\section{Metode}

Penelitian ini menggunakan pendekatan kuantitatif berfokus pada populasi dan sampel sebab akibatnya pada variabel. Populasi dalam penelitian ini adalah pegawai di Dinas Pariwisata dan Kebudayaan Kota Padang. Teknik sampel yang digunakan yaitu probability sampling, sehingga jumlah sampel yang digunakan adalah 57 orang. Pengumpulan data menggunakan kuesioner yang disebarkan kepada pegawai di Dinas Pariwisata dan Kebudayaan Kota Padang. Instrumen yang digunakan adalah kuesioner dengan skala Likert. Analisis data dalam penelitian ini menggunakan 
analisis data kualitatif dan analisis kuantitatif melalui statistika deskriptif dan inferensial. Instrumen sebelum diberikan kepada responden dilakukan uji validitas dan reliabilitas.

Uji validitas dipakai untuk mengetahui valid atau tidaknya sebuah angket. Apabila pertayaan pada angket bisa memprediksi objek penelitian, maka angket dapat dikatakan valid. Uji instrumen digunakan 2 prosedur ialah validitas menggunakan validitas dengan teknik Bivariate Pearson Product Moment Correlations dan uji validitas menggunakan Alpha Cronbach's. Jika hasil pengujian instrumen validitas konsisten, maka angket/kuesioner tersebut dinyatakan mampu dan dapat diandalkan. Setelah diberikan kepada responden, kuesioner dianalisis dengan uji asumsi klasik terdiri dari uji normalitas, uji multikolinieritas, dan uji heterokedasitas. Uji hipotesis dilakukan dengan analisis regresi linier berganda.

\section{Hasil dan Pembahasan}

\section{Hasil Penelitian}

Varibel gaya kepemimpinan terdiri dari 13 item pernyataan. Hasil uji penelitian pada varibel gaya kepemimpinan di Dinas Pariwisata dan Kebudayaan Kota Padang dapat dilihat pada tabel 1 berikut ini .

Tabel 1. Data Statistik Gaya Kepemimpinan

\begin{tabular}{cc}
\hline Statistik & Skor \\
\hline Mean & 57,07 \\
Median & 58,00 \\
Mode & 60 \\
Std. Deviation & 4,288 \\
Variance & 18,388 \\
Range & 21 \\
Minimum & 43 \\
Maximum & 64 \\
Sum & 3253 \\
\hline
\end{tabular}

Pada tabel tersebut diketahui bahwa hasil penelitian variabel gaya kepemimpinan dari jawaban responden menunjukkan bahwa skor terendah (minimum) 43 dan skor tertinggi (maximum) 64. Berdasarkan distribusi skor tersebut diperoleh nilai rata-rata (mean) sebesar 57,07, skor tengah (median) 58.00, skor yang sering muncul (mode) 60, simpang baku (standar deviation) 4.288, range 21, dan variance 18.388. Selanjutnya, disajikan klarifikasi skor pencapaian responden untuk menggambarkan kategori penilaian hasil penelitian pada tabel 2.

Tabel 2. Deskripsi Data Variabel Gaya Kepemimpinan

\begin{tabular}{|c|c|c|c|}
\hline Kategori & Kelas Interval & Frekuensi & (\%) \\
\hline Sangat setuju & $\geq 51,9$ & 51 & $89,4 \%$ \\
\hline Setuju & $43.3-<51,9$ & 5 & $8,7 \%$ \\
\hline Kurang setuju & $34,7-<43,3$ & 1 & $1,7 \%$ \\
\hline Tidak setuju & $26,1-<34,7$ & - & - \\
\hline Sangat tidak setuju & $<26,1$ & - & - \\
\hline \multicolumn{2}{|c|}{ Total } & 57 & $100 \%$ \\
\hline
\end{tabular}

Pada tabel di atas diketahui bahwa variabel gaya kepemimpinan $(X)$ sebanyak $89,4 \%$ responden termasuk dalam kategori sangat setuju, 8,7\% responden termasuk dalam kategori setuju dan $1,7 \%$ responden termasuk dalam kategori kurang setuju. Selanjutnya, pada variabel motivasi kerja terdiri dari 17 item pernyataan yang telah diuji validitas dan reliabilitasnya. Data yang diperoleh 
dari hasil penelitian pada variabel motivasi kerja pada pegawai di Dinas Pariwisata dan Kebudayaan Kota Padang dapat dilihat pada tabel 3 berikut ini.

Tabel 3. Data Statistik Motivasi Kerja

\begin{tabular}{cc}
\hline Statistik & Skor \\
\hline Mean & 75,70 \\
Median & 76,00 \\
Mode & 77 \\
Std. Deviation & 3,982 \\
Variance & 15,856 \\
Range & 24 \\
Minimum & 61 \\
Maximum & 85 \\
Sum & 4315 \\
\hline
\end{tabular}

Dari tabel 3 diketahui bahwa hasil penelitian variabel motivasi kerja dari jawaban responden menunjukkan skor terendah (minimum) 61 dan skor tertinggi (maximum) 85. Berdasarkan distribusi skor tersebut diperoleh nilai rata-rata (mean) sebesar 75.70, skor tengah (median) 76.00, skor yang sering muncul (mode) 77, simpang baku (standar deviation) 3.982, range 24, dan variance 15.856. Selanjutnya, disajikan klarifikasi skor pencapaian responden untuk menggambarkan kategori penilaian hasil penelitian pada tabel 4 berikut ini,

Tabel 4. Deskripsi Data Variabel Motivasi Kerja

\begin{tabular}{|c|c|c|c|}
\hline Kategori & Kelas Interval & Frekuensi & (\%) \\
\hline Sangat setuju & $\geq 67,95$ & 55 & $96,5 \%$ \\
\hline Setuju & $56,65-<67,95$ & 2 & $3,5 \%$ \\
\hline Kurang setuju & $45,35-<56,65$ & - & - \\
\hline Tidak setuju & $34,05-45,35$ & - & - \\
\hline Sangat tidak setuju & $<34,05$ & - & - \\
\hline \multicolumn{2}{|c|}{ Total } & 57 & $100 \%$ \\
\hline
\end{tabular}

Dari tabel di atas diketahui bahwa variabel motivasi kerja sebanyak 96,5\% responden termasuk dalam kategori sangat setuju, 3,5\% responden termasuk dalam kategori setuju. Berdasarkan pengategorian skor dan niai rata-rata pada statistik hasil penelitian, terlihat bahwa penilaian pegawai mengenai motivasi kerja sebesar $96,5 \%$ pada rentang $\geq 67,95$ dalam kategori sangat setuju. Uji persyaratan analisis pertama dilakukan uji normalitas. Pengujan normalitas mengenai pengaruh gaya kepemimpinan dengan motivasi kerja pegawai di Dinas Pariwisata dan Kebudayaan Kota Padang dengan menggunakan uji Kolmogorov Smirnov. Dalam penelitian ini, taraf signifikansi yang digunakan sebagai dasar menolak dan menerima keputusan normal atau tidaknya suatu distribusi adalah 0.05. Hasil uji normalitas adalah 0,987. Nilai tersebut lebih besar dari 0.05 . Dengan demikian, dapat disimpulkan bahwa nilai residual berdistribusi normal. Selanjutnya, dilakukan uji homogenitas dengan uji Test of homogeneity of variences. Penelitian ini taraf signifikansi yang digunakan sebagai dasar menentukan keputusan sama atau tidaknya suatu varience pada distribusi adalah 0.05 .

Berdasarkan hasil uji homogenitas pada tabel di atas, diperoleh nilai sig adalah 0.106 dengan taraf signifikansi $>0.05$. Artinya, nilai signifikansi data lebih besar dari taraf signifikansi. Dengan demikian, dapat disimpulkan bahwa data berasal dari populasi yang memiliki varience yang sama atau homogen. Selanjutnya, dilakukan uji linearitas yang bertujuan untuk mengetahui dua variabel mempunyai hubungan yag linear atau tidak secara signifikan. Data yang diperoleh dalam penelitian ini dengan menguji linearitas disajikan pada tabel 5 berikut ini. 
Tabel 5. Uji Linearitas

\begin{tabular}{|c|c|c|c|c|c|c|c|}
\hline \multicolumn{8}{|l|}{ ANOVA Table } \\
\hline & & & $\begin{array}{l}\text { Sum } \\
\text { Squares }\end{array}$ & $d f$ & $\begin{array}{l}\text { Mean } \\
\text { Square }\end{array}$ & $\mathrm{F}$ & Sig. \\
\hline \multirow{5}{*}{$\begin{array}{l}\text { Motivasi Kerja } \\
\text { Gaya } \\
\text { Kepemimpinan }\end{array}$} & \multirow{3}{*}{$\begin{array}{l}\text { Between } \\
\text { Groups }\end{array}$} & (Combined) & 654,449 & 16 & 40,903 & 7,008 & 0,000 \\
\hline & & Linearity & 243,945 & 1 & 243,945 & 41,793 & 0,000 \\
\hline & & $\begin{array}{l}\text { Deviation from } \\
\text { Linearity }\end{array}$ & 410,504 & 15 & 27,367 & 4,689 & 0,000 \\
\hline & \multicolumn{2}{|c|}{ Within Groups } & 233,481 & 40 & 5,837 & & \\
\hline & \multicolumn{2}{|l|}{ Total } & 887,930 & 56 & & & \\
\hline
\end{tabular}

Berdasarkan hasil uji linearitas di atas, pada SPSS 20.00 diperoleh nilai signifikansi 0.000 . Nilai tersebut menunjukkan $>0.05$, sehingga dapat disimpulkan bahwa tidak terdapat hubungan linear secara signifikan antara gaya kepemimpinan (X) dan motivasi kerja ( $\mathrm{Y}$ ). Pengujian hipotesis digunakan untuk mengetahui derajat hubungan antara variabel bebas dan variabel terikat. Uji regresi linear sederhana yang menyatakan seberapa jauh perubahan antara variabel $\mathrm{X}$ dan variabel $\mathrm{Y}$. Hasil uji regresi linear sederhana dapat dilihat pada tabel 6 berikut ini.

Tabel 6. Nilai Signifikansi

\begin{tabular}{llrrrrr}
\hline Model & & Sum of Squares & Df & Mean Square & F & \multicolumn{1}{c}{ Sig. } \\
\hline \multirow{2}{*}{1} & Regression & 243,945 & 1 & 243,945 & 20,834 & 0,000 \\
& Residual & 643,985 & 55 & 11,709 & & \\
& Total & 887,930 & 56 & & & \\
\hline
\end{tabular}

Berdasarkan hasil uji anova di atas, nilai $\mathrm{F}$ hitung 20.834 dengan Sig 0,000 $<0.05$, maka model regresi dapat dipakai. Artinya, gaya kepemimpinan berpengaruh secara signifikan terhadap motivasi kerja pegawai. Selanjutnya, untuk mengetahui besar koefisien regresi antara variabel gaya kepemimpinan $(\mathrm{X})$ terhadap motivasi kerja $(\mathrm{Y})$, maka hasilnya dapat dilihat pada tabel 7 di bawah ini.

Tabel 7. Koefisien Regresi Variabel $X$ terhadap Variabel $Y$

\begin{tabular}{llrrrrr}
\hline Model & \multicolumn{3}{c}{ Unstandardized Coefficients } & $\begin{array}{c}\text { Standardized } \\
\text { Coefficients }\end{array}$ & T & Sig. \\
\cline { 3 - 5 } & & \multicolumn{1}{c}{ B } & Std. Error & \multicolumn{1}{c}{ Beta } & & \\
\hline \multirow{2}{*}{1} & (Constant) & 47,924 & 6,102 & & 7,853 & 0,000 \\
& Gaya kepemimpinan & 0,487 & 0,107 & 0,524 & 4,564 & 0,000 \\
\hline
\end{tabular}

Pada tabel di atas didapatkan persamaan regresi sebagai berikut.

$$
\begin{aligned}
& Y=a+b X \\
& Y=47.924+0.487 X
\end{aligned}
$$

Berdasarkan persamaan di atas diperoleh koefisien regresi sebesar 0.487 dengan nilai Sig $0.000<0.05$. Artinya, setiap peningkatan sebesar 1 satuan gaya kepemimpinan akan meningkatkan 0.487 satuan motivasi kerja pegawai. Selanjutnya, untuk melihat pengaruh varibel gaya kepemimpinan $(\mathrm{X})$ terhadap Motivasi kerja $(\mathrm{Y})$, maka hasilnya dapat dilihat pada tabel dibawah ini :

Tabel 8. Hasil Uji R Square Variabel $X$ dan $Y$

\begin{tabular}{llllll}
\hline Model & $\mathbf{R}$ & R Square & AdjustedR Square & $\begin{array}{l}\text { Std. Error of the } \\
\text { Estimate }\end{array}$ & \\
\hline 1 & 0,524 & 0,275 & 0,262 & 3,422 & \\
\hline
\end{tabular}


Berdasarkan tabel di atas, diperoleh nilai R Square sebesar 0.275 . Artinya, pengaruh variabel $X$ terhadap variabel $Y$ adalah sebesar $27 \%$, sedangkan $73 \%$ dipengaruhi oleh faktor lain. Hasil analisis yang telah dilakukan pada 57 sampel mengenai gaya kepemimpinan, motivasi kerja, serta pengaruh antara kedua variabel tersebut. Gaya kepemimpinan terdiri dari 6 indikator. Pada indikator kemampuan mengambil keputusan dengan persentase $84,2 \%$ yang termasuk dalam kategori sangat setuju, pada indikator kemampuan memotivasi dengan persentase $89,4 \%$ termasuk dalam kategori sangat baik, pada indikator kemampuan komunikasi $94,7 \%$ termasuk dalam kategori sangat baik dan pada indikator mengendalikan bawahan dengan persentase $89,4 \%$ dalam kategori sangat baik. Sedangkan indikator bertanggung jawab dengan persentase $86 \%$ termasuk dalam kategori sangat baik, dan pada indikator terakhir kemampuan mengendalikan emosional dengan persentase $98 \%$ termasuk dalam kategori sangat baik. Berdasarkan penjelasan tersebut diketahui bahwa gaya kepemiminan di Dinas Pariwisata dan Kebudayaan Kota Padang berada pada kategori sangat baik.

Hasil deskripsi data per indikator dapat dikelompokan menjadi 5 sebagai berikut. Indikator kebutuhan fisiologis berada pada kategori sangat baik dengan persentase $93 \%$, Indikator kebutuhan rasa aman berada pada kategori sangat baik dengan persentase $100 \%$. Indikator kebutuhan hubungan sosial berada pada kategori sangat baik dengan persentase $98,2 \%$. Indikator pengakuan berada pada kategori sangat baik dengan persentase 96,5\%, dan indikator aktualisasi diri berada pada kategori sangat baik dengan persentase 96,5\%. Dapat disimpulkan bahwa variabel motivasi kerja tergolong pada kategori sangat baik. Hal tersebut dapat mendorong instansi lebih baik lagi. Pada hasil pengujian hipotesis dengan uji Regresi linear sederhana diperoleh $\mathrm{F}$ hitung 20.834 dengan sign $0,000<0,05$. Ini berarti bahwa variabel gaya kepemimpinan $(X)$ berpengaruh secara signifikan terhadap variabel motivasi Kerja (Y) maka Ha diterima. Diperoleh R Square sebesar 0.275 artinya pengaruh variabel $X$ terhadap variabel $Y$ adalah sebesar $27 \%$, sedangkan $73 \%$ dipengaruhi oleh faktor klain. Gaya kepemimpinan berpengaruh terhadap motivasi kerja sebesar 27\%, sehingga dapat disimpulkan bahwa gaya kepemimpinan yang baik pada suatu instansi dapat meningkatkan motivasi kerja pegawainya.

Hasil penelitian menunjukkan bahwa gaya kepemimpinan berpengaruh terhadap motivasi kerja pegawai. Hal ini menunjukkan bahwa semakin tinggi gaya kepemimpinan akan mengakibatkan tinggi pula motivasi kerja pegawai. Temuan ini diperkuat dengan penelitian sebelumnya yang menyatakan gaya kepemimpinan memberikan pengaruh positif terhadap motivasi kerja karyawan. (Tolu et al., 2021). Motivasi sebagai proses yang ikut menentukan intensitas, arah, dan ketekunan individu dalam usaha mencapai sasaran. Jadi, motivasi merupakan upaya yang ada dalam diri seseorang dalam memenuhi kebutuhannya guna mencapai tujuan organisasi (Gaya \& Terhadap, 2021; Istiqomah \& Suhartini, 2015). Motivasi merupakan kekuatan pendorong yang akan mewujudkan suatu perilaku guna mencapai tujuan kepuasan dirinya. Motivasi terbentuk dari sikap seseorang pegawai dalam menghadapi situasi kerja. Motivasi merupakan kondisi yang menggerakkan diri pegawai yang terarah untuk mencapai tujuan organisasi dan sikap mental merupakan kondisi mental yang mendorong diri pegawai untuk berusaha mencapai prestasi kerja secara maksimal (Jannah et al., 2021; Rachmawati, 2017) .

Temuan selanjutnya yaitu motivasi berpengaruh langsung dan tidak langsung terhadap peningkatan kinerja pegawai pada Dinas Pariwisata dan Kebudayaan Kota Padang. Kinerja adalah hasil kerja secara kualitas dan kuantitas yang dicapai seorang pegawai dalam melaksanakan tugasnnya sesuai dengan tanggung jawab yang diberikan kepadanya (Marjaya \& Pasaribu, 2019; Nur et al., 2020; Wandi et al., 2019). Kinerja merupakan suatu gambaran mengenai tingkat pencapaian pelaksanaan suatu kegiatan/program/kebijakan dalam mewujudkan sasaran, tujuan, misi, visi, serta organisasi. Pada dasarnya pengertian kinerja berkaitan dengan tanggung jawab individu atau organisasi dalam menjalankan apa yang menjadi wewenang dan tanggung jawab yang diberikan kepadanya. Pihak instansi harus selalu memperhatikan kesejahteraan karyawan melalui gaji, jaminan kesehatan, tunjangan hari raya dan lainnya. Atau menciptakan hubungan sosial yang baik antar rekan kerja, sehingga motivasi kerja pegawai akan tetap baik. Pihak instansi harus mempertahankan hal tesebut, sehingga fungsi manajemen dan sumber daya dapat berjalan dengan baik. Hasil penelitian 
diperkuat dengan penelitian sebelumnya yang menunjukkan gaya kepemimpinan memberikan pengaruh terhadap motivasi kerja pegawai (Gaya \& Terhadap, 2021; MS et al., 2020).

\section{Simpulan}

Berdasarkan hasil penelitian dan pembahasan, maka gaya kepemimpinan berpengaruh positif terhadap motivasi kerja pegawai. Gaya kepemimpinan secara parsial mempunyai pengaruh pada pegawai Dinas Pariwisata dan Kebudayaan Kota Padang. Kendala dalam melakukan penelitian ini yaitu sampel yang digunakan dengan jumlah sedikit. Selain itu, penyebaran instrumen membutuhkan waktu yang cukup lama karena harus menunggu jam istirahat dari pegawai. Penelitian selanjutnya dapat menambahkan variabel lain yang dapat berpengaruh pada kinerja karena dari penelitian ini masih ada faktor gaya kepemimpinan berpengaruh kecil terhadap motivasi kerja pegawai kinerja dan masih ada faktor lain yang bisa memengaruhi kinerja. Adanya penelitian ini diharapkan dapat menjadi gambaran atau masukan bagi instansi untuk meningkatkan gaya kepemimpinan dengan baik.

\section{Daftar Pustaka}

Amyana, A. M., Dantes, N., \& Suarni, N. K. (2014). Korelasi antara Disiplin Kerja, Motivasi Kerja, dan Kompetensi Pedagogik terhadap Kinerja Guru dalam Mengelola Pembelajaran Anak Berkebutuhan Khusus Slbb .... Jurnal Administrasi, 5. http://119.252.161.254/ejournal/index.php/jurnal_ap/article/view/1328.

Cahyadi, B. (2019). Pengaruh Gaya Kepemimpinan dan Lingkungan Kerja terhadap Kinerja Karyawan dalam Perspektif Islam. Amwaluna: Jurnal Ekonomi Dan Keuangan Syariah, 3(1), 29-40. https://doi.org/10.29313/amwaluna.v3i1.4141.

Dewi, N. N. (2021). Pengaruh Motivasi Disiplin Kerja dan Pengawasan terhadap Kinerja. Aksara: Jurnal IImu Pendidikan Nonformal, 7(2), 355. https://doi.org/10.37905/aksara.7.2.355366.2021.

Farhah, A., Ahiri, J., \& Ilham, M. (2020). Pengaruh Motivasi Kerja dan Disiplin Kerja terhadap Kinerja Karyawan. Jurnal Online Program Studi Pendidikan Ekonomi, 5(1), 1. https://doi.org/10.36709/jopspe.v5i1.13326.

Gaya, P., \& Terhadap, K. (2021). Pengaruh Gaya Kepemimpinan terhadap Motivasi Kerja Pegawai di Dinas Ketahanan Pangan Kabupaten Nias Selatan. Jurnal IImiah Mahasiswa, 4(2), 128-134. http://jurnal.stienisel.ac.id/index.php/jim/article/view/230.

Hanafi, A., \& Zulkifli, Z. (2018). Pengaruh Lingkungan Kerja dan Disiplin Kerja serta Motivasi Kerja terhadap Kinerja Karyawan. JURNAL DIMENSI, 7(2). https://doi.org/10.33373/dms.v7i2.1702.

Istiqomah, S. N., \& Suhartini, S. (2015). Pengaruh Disiplin Kerja dan Iklim Komunikasi terhadap kinerja Pegawai Dinas Perhubungan Kota Yogyakarta dengan Kerja sebagai Variabel Intervening. Jurnal Siasat Bisnis, 19(1), 89-97. https://doi.org/10.20885/jsb.vol19.iss1.art8.

Jannah, N. A., Sazly, S., \& Kartawijaya, F. (2021). Pengaruh Gaya Kepemimpinan terhadap Motivasi Kerja pada Kantor Unit PTSP Kota Administrasi Jakarta Barat. Jurnal Administrasi Bisnis, 1(1), 9-18. http://jurnal.bsi.ac.id/index.php/jab/article/view/299.

Marjaya, I., \& Pasaribu, F. (2019). Pengaruh Kepemimpinan, Motivasi, dan Pelatihan terhadap Kinerja Pegawai. Jurnal Ilmiah Magister Manajemen, 2(1), 129-147. https://doi.org/10.30596\%2Fmaneggio.v2i1.3650.

Meilany, P., \& Ibrahim, M. (2015). Pengaruh Disiplin Kerja terhadap Kinerja Karyawan (Kasus Bagian Operasional PT Indah Logistik Cargo Cabang Pekanbaru). Jurnal FISIP, 2(2), 1-11.

MS, M. Z., Yamali, F. R., \& Irfani, A. (2020). Pengaruh Gaya Kepemimpinan Kepemimpinan dan Penempatan Pegawai terhadap Motivasi Kerja serta Dampaknya pada Kinerja Pegawai di Biro Umum Setda Provinsi Jambi. J-MAS (Jurnal Manajemen Dan Sains), 5(2), 276. https://doi.org/10.33087/jmas.v5i2.195.

Nabawi, R. (2019). Pengaruh Lingkungan Kerja, Kepuasan Kerja, dan Beban Kerja terhadap Kinerja 
Pegawai. Maneggio: Jurnal Ilmiah Magister Manajemen, 2(2), 170-183. https://doi.org/10.30596/maneggio.v2i2.3667.

Nur, M., Nurkaidah, N., \& Nonci, N. (2020). Gaya Kepemimpinan dan Sumber Daya Manusia terhadap Kinerja Pegawai pada Kantor Sekretariat Daerah Kabupaten Majene. Jurnal Paradigma Administrasi Negara, 2(1), 24-31. https://journal.unibos.ac.id/paradigma/article/view/107.

Rachmawati, R. W. (2017). Pengaruh Pelatihan dan Motivasi Kerja terhadap Kinerja Karyawan Pt. Bank Bjb Kantor Cabang Suci Bandung. Jurnal Manajemen Dan Pemasaran Jasa, 9(1), 1. https://doi.org/10.25105/jmpj.v9i1.802.

Rafiditya, A., \& Syarifuddin. (2020). Pengaruh Self Esteem dan Self Efficacy terhadap Kinerja Karyawan PT Dana Tabungan dan Asuransi Pegawai Negeri Kantor Cabang Utama Bandung. E-Procceding of Management, 7(2), 4143-4150.

Rialmi, Z. (2020). Pengaruh Kedisiplinan terhadap Kinerja Karyawan pada PT Bhakti Karya Distribusi Indonesia. JENIUS (Jurnal IImiah Manajemen Sumber Daya Manusia), 3(3), 286-293. https://doi.org/10.32493/JJSDM.v3i3.4866.

Sanders, M. G., Lukmansyah, D., Danniarti, R., \& Moh. Rois, Fartika Ifriqia, D. S. (2017). Jurnal Manajemen, Kepemimpinan, dan Supervisi Pendidikan Volume 1, No. 1, Juli-Desember 2017. American Journal of Education, 1(2), 233-255. The Value of Pancasila, National Insight, PPKn Subject

Suherman, H. (2018). Pengaruh Gaya Kepemimpinan dan Disiplin Kerja terhadap Kinerja Karyawan PT Selaras Karya Raya Jakarta. JENIUS (Jurnal IImiah Manajemen Sumber Daya Manusia), 2(1), 1-14. https://doi.org/10.32493/jjsdm.v2i1.1932.

Tolu, A., Mamentu, M., \& Rumawas, W. (2021). Pengaruh Gaya Kepemimpinan, Lingkungan Kerja, dan Motivasi Kerja terhadap Kinerja Pegawai. Jurnal Administrasi Bisnis, 11(1), 7-13. https://doi.org/10.35797/jab.11.1.2021.33535.7-13.

Wandi, D., Adha, S., \& Asriyah, I. (2019). Pengaruh Komunikasi terhadap Kinerja Pegawai pada Badan Penanggulangan Bencana Daerah (BPBD) Provinsi Banten. Jurnal Ekonomi Vokasi, 2(2), 1830, ISSN:1098-6596. https://e-jurnal.Ippmunsera.org/index.php/JEV/article/view/1487.

Wardany, D. K. (2020). Kontribusi Kepemimpinan dan Kompetensi Profesional terhadap Kinerja Guru. Jurnal Madinasika Manajemen Dan Keguruan, 1(2), 73-82. 